\title{
Total Phenolics and Antioxidant Potentials of Rotula aquatica Lour
}

\author{
M. Pallavi ${ }^{1}$, C. K. Ramesh ${ }^{1}$, V. Krishna ${ }^{2}$, G. H. Channakeshava ${ }^{3}$, K. S. Jamuna ${ }^{1}$ \\ ${ }^{1}$ Molecular Biomedicine Laboratory, PG Dept. of Studies and Research in Biotechnology, Sahyadri Science College, Kuvempu University, Shimoga - 577 \\ 203, Karnataka, India. ${ }^{2}$ PG Dept. of Studies and Research in Biotechnology and Bioinformatics, Kuvempu University, Jnana Sahyadri, Shankaraghatta - \\ 577 451, Shimoga, Karnataka, India. ${ }^{3}$ Sri Raghavendra Ayurvedic Medical College, Malladihalli, Chitradurga District, Karnataka, India.
}

\section{ARTICLE INFO}

Article history:

Received on: 08/12/2015

Revised on: 22/12/2015

Accepted on: 24/01/2016

Available online: 30/04/2016

Key words:

Rotula aquatica Lour, in vitro antioxidant activities, radical scavenging and total phenolics.

\begin{abstract}
Rotula aquatica Lour is a small branched shrub that grows characteristically among rocks and trailing over gravel in stream beds. It belongs to the family Boraginaceae and widely distributed throughout India. It is commonly called as Pasanabheda. The present study was aimed to evaluate the total phenolics and in vitro antioxidant activity in root and leaf extracts of Rotula aquatica Lour. The dried roots and leaves were subjected to soxhlet extraction utilizing chloroform and methanol followed by preliminary qualitative phytochemical analysis. Total phenolic content was estimated by Folin-Ciocalteu method and in vitro antioxidant assays were performed using various radical scavenging activities viz. DPPH, superoxide anion, nitric oxide, hydroxyl and iron chelating activities at different concentrations. The results of the total phenolic content estimation was expressed in terms of equivalence with standard and the antioxidant potentiality of various scavenging and chelating activity were expressed in terms of $\mathrm{IC}_{50}$ values. The results showed that both root and leaves possess significant antioxidant activity even though the former was found to be superior than the latter in terms of parameters assessed. Further the methanol extracts were proved to be an ideal for the materials subjected to investigation.
\end{abstract}

\section{INTRODUCTION}

Free radicals and related species have attracted a great deal of attention in recent years. They are mainly derived from oxygen (reactive oxygen species/ROS) and nitrogen (reactive nitrogen species/RNS), and are generated in our body by various endogenous systems, exposure to different physicochemical conditions or pathophysiological states (Devasagayam et al., 2004).

To protect the cells and organ systems of the body against reactive oxygen species, humans have evolved a highly sophisticated and complex antioxidant protection system, that functions interactively and synergistically to neutralize free radicals. Thus, antioxidants are capable of stabilizing or deactivating free radicals before they attack cells (Beris, 1991). Antioxidants are absolutely critical for maintaining optimal

\footnotetext{
* Corresponding Author

Ramesh C K, Molecular Biomedicine Laboratory, PG Dept. of Studies and Research in Biotechnology, Sahyadri Science College, Kuvempu University, Shimoga - 577 203, Karnataka (INDIA)

Email:ckramck[at]gmail.com
}

cellular and systemic health and well-being. The relation between free radicals and disease can be explained by the concept of 'oxidative stress' elaborated by Sies (1986). The recent years have witnessed resurgence of interest in herbal drugs globally as more people are turning to the use of herbal medicinal products in health care (Suvakanta et al., 2005).

Therefore, the need exists for safe, economic, powerful and natural antioxidants to replace the synthetic ones. Obviously, there has been an increasing demand to evaluate the antioxidant properties of direct plant extracts (Clements and Decker, 2000; Nahak and Sahu, 2010).

The plant Rotula aquatica belongs to the family Boraginaceae reported to contain baunerol, steroids, alkaloids and allantoin. The root extract of Rotula aquatica showed antimitotic activity, diuretic activity due to the presence of allantoin and it is also used as a laxative, in treatment of piles and in venereal diseases. The alcoholic extract of Rotula aquatica also reported to be effective against ethylene glycol induced urolithiasis in albino rat (Rastogi and Mehrotra, 1959; Patil et al., 2004). The present research programme was aimed to investigate the total phenolics and free radical scavenging activities in roots and leaves extracts of Rotula aquatica Lour. 


\section{MATERIALS AND METHODS}

\section{Plant Material}

Roots and leaves of Rotula aquatica (Fig 1) were collected from rocky beds of river Bhadra, $2 \mathrm{Km}$ away from Kuvempu University campus, Shivamogga, Karnataka and authenticated in the Department of Biotechnology, Kuvempu University.

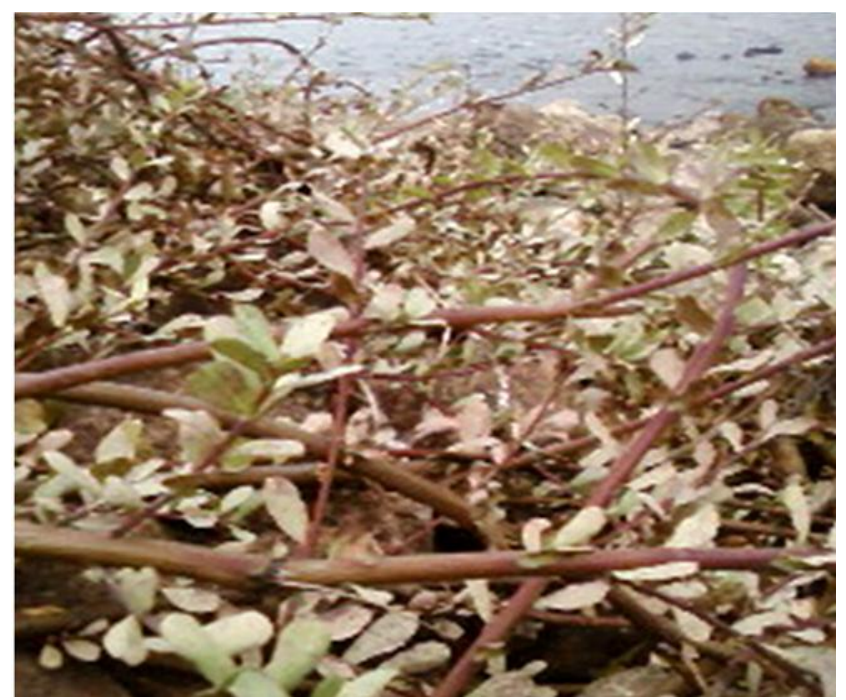

Fig. 1: Rotula aquatica plant.

\section{Preparation of extracts}

The fresh roots and leaves collected were thoroughly washed with tap water to make it free from soil particles, and then washed with distilled water. After washing, dried at room temperature and reduced to coarse powder. The powdered materials of Rotula aquatica were refluxed in a soxhlet extractor with the solvents Chloroform $\left(50-70^{\circ} \mathrm{C}\right.$, Merk Mumbai, India) and Methanol (Merk Mumbai, India) for $48 \mathrm{hrs}$ in batches of $250 \mathrm{~g}$ each. Every time, before extracting with the next solvent the powder was dried. The yield of crude extracts obtained from solvent were noted, stored in desiccators for maximum of 3 days; later preserved in a deep freezer $\left(-20^{\circ} \mathrm{C}\right)$ for further use.

\section{Qualitative phytochemical analysis}

The preliminary phytochemical studies were performed for testing the different chemical groups present in chloroform and methanolic extracts of Rotula aquatica roots and leaves (Trease and Evans, 1978; Kokate et al., 1990).

\section{Evaluation of in vitro antioxidant activities}

\section{General chemicals}

All chemicals and solvents used in the study were of analytical grade. DPPH (1, 1-diphenyl, 2-picryl hydrazyl), NBT (Nitro blue tetrazolium), NADH (Nicotinamide adenine dinucleotide phosphate reduced), PMS (Phenazinemethosulphate), TCA (Trichloro acetic acid), Ferric chloride and BHT (Butylatedhydroxy toluene), N-(1-Naphthyl)ethylenediamine dihydrochloride were obtained from Sigma chemical co USA. Ascorbic acid, Potassium chloride, sodium nitroprusside, 1,10phenanthroline and dimethyl sulphoxide were obtained from SD Fine chem. Ltd, Biosar, India. TBA (Thiobarbituric acid) and ferrozine were obtained from Hi media Mumbai, India. EDTA (Ethylene diamine tetra acetic acid), Pottassium ferric cyanide, tannic acid and Hydrogen peroxide $\left(\mathrm{H}_{2} \mathrm{O}_{2}\right)$ were obtained from Qualigens Fine chemicals, Mumbai, India.

\section{Total Phenolics}

Total polyphenolic compounds were determined according to a protocol similar to that of Chandler and Dodds, 1995. $1 \mathrm{ml}$ of the test extract was mixed with $1 \mathrm{ml}$ of $95 \%$ ethanol, $5 \mathrm{ml}$ of distilled water and $0.5 \mathrm{ml}$ of $50 \%$ Folin Ciocalteu reagent. The mixture was allowed to react for 5 minutes and $1 \mathrm{ml}$ of sodium carbonate was added. Thereafter, it was thoroughly mixed and placed in dark for 1hour. After one hour; the absorbance was measured at $725 \mathrm{~nm}$ using UV-Visible spectrophotometer. Using the standard gallic acid curve the total polyphenolic content was calculated. The concentration of polyphenols was expressed in terms of $\mu \mathrm{g} / \mathrm{mg}$ of sample.

\section{Preparation of Stock Solutions of extracts:}

The stock solutions of extracts were prepared by dissolving $100 \mathrm{mg}$ of dried extracts in $100 \mathrm{ml}$ of methanol to make a stock solution of $1 \mathrm{mg} / \mathrm{ml}$. Aliquots from this stock solution were further diluted with methanol to get the required concentrations of the extract.

\section{1, 1-Diphenyl 2-Picryl Hydrazyl (DPPH) radical scavenging activity}

The hydrogen atom or electron donating abilities of the extracts of Rotula aquatica was measured from the bleaching of the purple-coloured methanolic solution of 2,2-diphenyl-1picrylhydrazyl (DPPH). This spectrophotometric assay uses the stable radical DPPH as a reagent (Cuendet et al., 1997). Different concentrations of the extracts in methanol were added to $4 \mathrm{ml}$ of $0.004 \%$ methanol solution of DPPH. After 30 min incubation at room temperature, the absorbance was read against a blank at 517 $\mathrm{nm}$. Inhibition of free radical DPPH in percent (I\%) was calculated in the following way: $\%$ Inhibition $=\left(\left(\mathrm{A}_{0}-\mathrm{A}_{1}\right) / \mathrm{A}_{0} \times 100\right)$ where, $A_{0}$ is the absorbance of the control reaction (containing all reagents except the test compound) and $A_{1}$ is the absorbance of the test extract. The values of inhibition were calculated for the various concentrations of extract.

\section{Superoxide anion radical scavenging activity}

The scavenging activity of the Rotula aquatica extracts towards superoxide anion radicals was measured by the method of Liu et al., 1997. Superoxide anions were generated in a nonenzymatic phenazinemethosulfate-nicotinamide adenine dinucleotide (PMS-NADH) system through the reaction of PMS, $\mathrm{NADH}$, and oxygen. It was assayed by the reduction of nitrobluetetrazolium (NBT). In the experiment the superoxide 
anion was generated in $3 \mathrm{ml}$ of Tris- $\mathrm{HCl}$ buffer (100 mM, pH 7.4) containing $0.75 \mathrm{ml}$ of NBT $(300 \mu \mathrm{M})$ solution, $0.75 \mathrm{ml}$ of NADH $(936 \mu \mathrm{M})$ solution and different concentrations of the extract. The reaction was initiated by adding $0.75 \mathrm{ml}$ of PMS $(120 \mu \mathrm{M})$ to the mixture. After $5 \mathrm{~min}$ of incubation at room temperature, the absorbance at $560 \mathrm{~nm}$ was measured in spectrophotometer. The superoxide anion scavenging activity was calculated as explained previously.

\section{Nitric oxide radical scavenging activity}

Nitric oxide radical scavenging activity was determined according to the method reported by Garrat, 1964. Sodium nitroprusside in aqueous solution at physiological $p H$ spontaneously generates nitric oxide, which interacts with oxygen to produce nitrite ions, which can be determined by the use of the Griess Illosvoy reaction (Velavan et al., 2007). $2 \mathrm{ml}$ of $10 \mathrm{mM}$ sodium nitroprusside in $0.5 \mathrm{ml}$ phosphate buffer saline $(\mathrm{pH} 7.4)$ was mixed with various concentrations of the extracts and the mixture was incubated at $25^{\circ} \mathrm{C}$ for 150 minutes. From the incubated mixture $0.5 \mathrm{ml}$ was taken out and added into $1 \mathrm{ml}$ sulfanilic acid reagent $(0.33 \%$ in glacial acetic acid) and incubated at room temperature for 5 minutes. Finally, $1 \mathrm{ml}$ of $N-(1-$ Naphthyl)ethylenediamine dihydrochloride $(0.1 \% \mathrm{w} / \mathrm{v})$ was mixed and incubated at room temperature for 30 minutes. The absorbance at $540 \mathrm{~nm}$ was measured with a spectrophotometer. The Nitric oxide radicals scavenging activity was calculated as explained previously.

\section{Hydroxyl radical scavenging activity}

The scavenging activity for hydroxyl radical was measured by Fenton reaction (Yu et al., 2004). The hydroxyl radicals were generated in reaction mixture containing various concentrations of extracts with $60 \mu \mathrm{l}$ of $1.0 \mathrm{mM} \mathrm{FeCl}_{3}, 90 \mu \mathrm{l}$ of $1 \mathrm{mM} 1,10$-phenanthroline, $2.4 \mathrm{ml}$ of $0.2 \mathrm{M}$-phosphate buffer $(\mathrm{pH}$ 7.8) and $150 \mu \mathrm{l}$ of $0.17 \mathrm{M} \mathrm{H}_{2} \mathrm{O}_{2}$. Adding the $\mathrm{H}_{2} \mathrm{O}_{2}$ started the reaction. After incubation at room temperature for 5 minutes, the absorbance of mixture at $560 \mathrm{~nm}$ was measured with a spectrophotometer. The hydroxyl radicals scavenging activity was calculated as explained previously.

\section{$\mathrm{Fe}^{2+}$ chelating activity}

The chelating activity for the extracts for ferrous ions $\mathrm{Fe}^{2+}$ was measured according to the method of Dinis et al., 1994. To the different concentrations of the extracts, $1.6 \mathrm{ml}$ of deionised water and $0.05 \mathrm{ml}$ of $2 \mathrm{mM} \mathrm{FeCl} \mathrm{m}_{2}$ were added.

After 30 seconds, $0.1 \mathrm{ml}$ of $5 \mathrm{mM}$ ferrozine was added. Ferrozine reacted with divalent iron to form stable magenta complex species that were very soluble in water. After 10minutes at room temperature, the absorbance of the $\mathrm{Fe}^{2+}$ Ferrozine complex was measured at $562 \mathrm{~nm}$. The chelating activity of the extract for $\mathrm{Fe}^{2+}$ was calculated as: Chelating rate $(\%)=$ $\left(\left(A_{0}-A_{1}\right) / A_{0} \times 100\right)$ where, $A_{0}$ is the absorbance of the control (without test samples) and $A_{1}$ is the absorbance of test samples.

\section{RESULTS AND DISCUSSION}

\section{Extraction Yield}

Methanolic and chloroform extracts of both leaves and roots of Rotula aquatica were weighed and the yields obtained were noted. $R$. aquatica roots methanol extract showed $38.97 \mathrm{~g}$ and leaves methanol extract revealed $30.59 \mathrm{~g}$. In chloroform extracts of $R$. aquatica, roots showed $15.52 \mathrm{~g}$ whereas leaves showed $18.56 \mathrm{~g}$ (Table 1).

Table 1: Extraction yield of roots and leaves of Rotula aquatica.

\begin{tabular}{cccc}
\hline $\begin{array}{r}\text { Sl } \\
\text { No. }\end{array}$ & Plant Extracts & $\begin{array}{c}\text { Chloroform } \\
\text { Extract }\end{array}$ & $\begin{array}{c}\text { Methanol } \\
\text { extract }\end{array}$ \\
\hline 1. & Rotula aquatica Roots & $15.52 \mathrm{~g}$ & $38.97 \mathrm{~g}$ \\
2. & Rotula aquatica Leaves & $18.56 \mathrm{~g}$ & $30.59 \mathrm{~g}$ \\
\hline
\end{tabular}

\section{Qualitative phytochemical analysis}

The preliminary qualitative phytochemical analysis revealed that both the methanolic and chloroform extract of Rotula aquatica roots and leaves showed the presence of carbohydrates, proteins, amino acids and glycosides. Steroids and triterpenoids are present in chloroform extracts whereas absent in methanolic extracts of both. Saponins showed presence only in methanol extracts of root and leaves. Quinones were present in both leaf extracts and in root chloroform extract. Alkaloids, tannins and polyphenols are present in chloroform and methanol extracts of both leaves and roots. Flavonoids showed positive for chloroform extract of root and methanol extracts of both leaves and root. The results of the analysis are shown in Table 2.

Table 2: Results of Qualitative analysis for Phytoconstituents in Rotula aquatica.

\begin{tabular}{|c|c|c|c|c|}
\hline \multirow[b]{2}{*}{ Tests } & \multicolumn{2}{|c|}{ leaf extracts } & \multicolumn{2}{|c|}{ root extracts } \\
\hline & 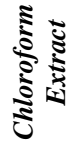 & 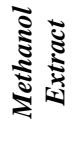 & 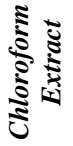 & 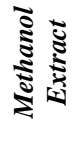 \\
\hline Carbohydrates & + & + & + & + \\
\hline Proteins & + & + & + & + \\
\hline Amino Acids & + & + & + & + \\
\hline Steroids & + & - & + & - \\
\hline Triterpenoids & + & - & + & - \\
\hline Glycosides & + & + & + & + \\
\hline Saponins & - & + & - & + \\
\hline Alkaloids & + & + & + & + \\
\hline Quinones & + & + & + & - \\
\hline Flavanoids & - & + & + & + \\
\hline Tannins \& Polyphenols & + & + & + & + \\
\hline
\end{tabular}

\section{Evaluation of in vitro antioxidant activities}

\section{Total Phenolics}

The total amount of phenolic contents was present in varied concentrations in the different extracts of Rotula aquatica. The methanolic extract of root showed highest concentration of phenolics $(55.2 \pm 0.02 \mu \mathrm{g} / \mathrm{mg})$ followed by chloroform extract $(48.4 \pm 0.1 \mu \mathrm{g} / \mathrm{mg})$, while the leaf methanolic and chloroform extract recorded $(44.9 \pm 0.03 \mu \mathrm{g} / \mathrm{mg})$ and $(34.7 \pm 0.3 \mu \mathrm{g} / \mathrm{mg})$ respectively (Fig 2a and b). 

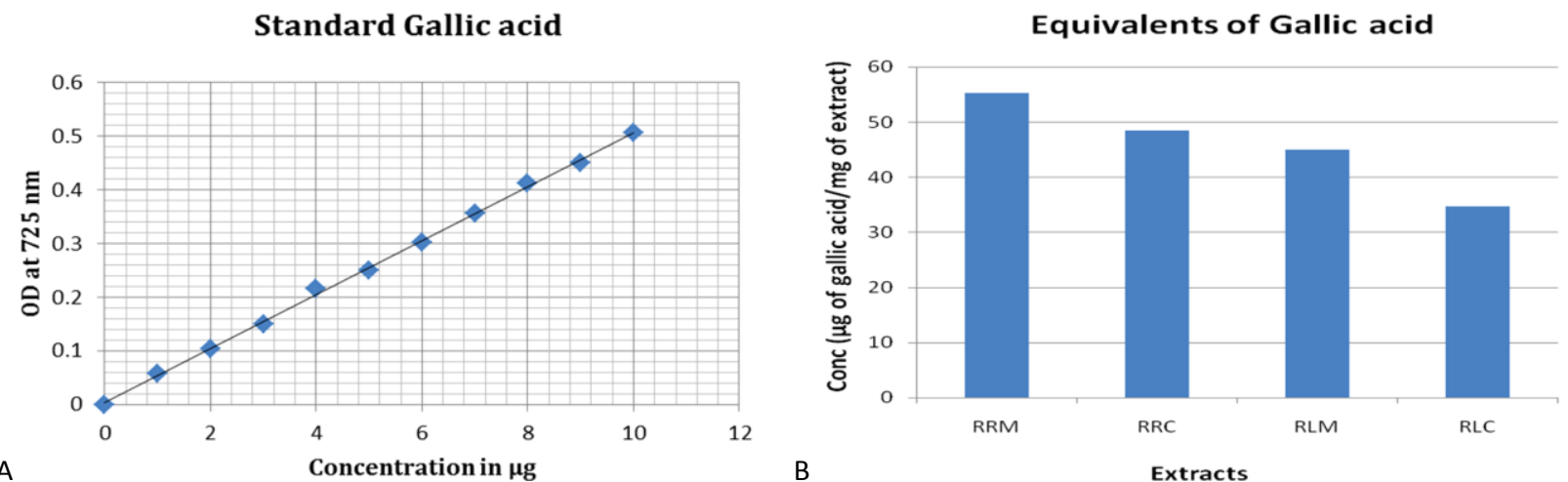

Fig. 2: Total phenolics of Rotula aquatica root extracts in Equivalents of gallic acid (a) Standard curve of gallic acid (b) Equivalents of gallic acid (RRM-Rotula aquatica root methanol extract, RRC- Rotula aquatica root chloroform extract, RLM-Rotula aquatica leaf methanol extract and RLC-Rotula aquatica leaf chloroform extract)

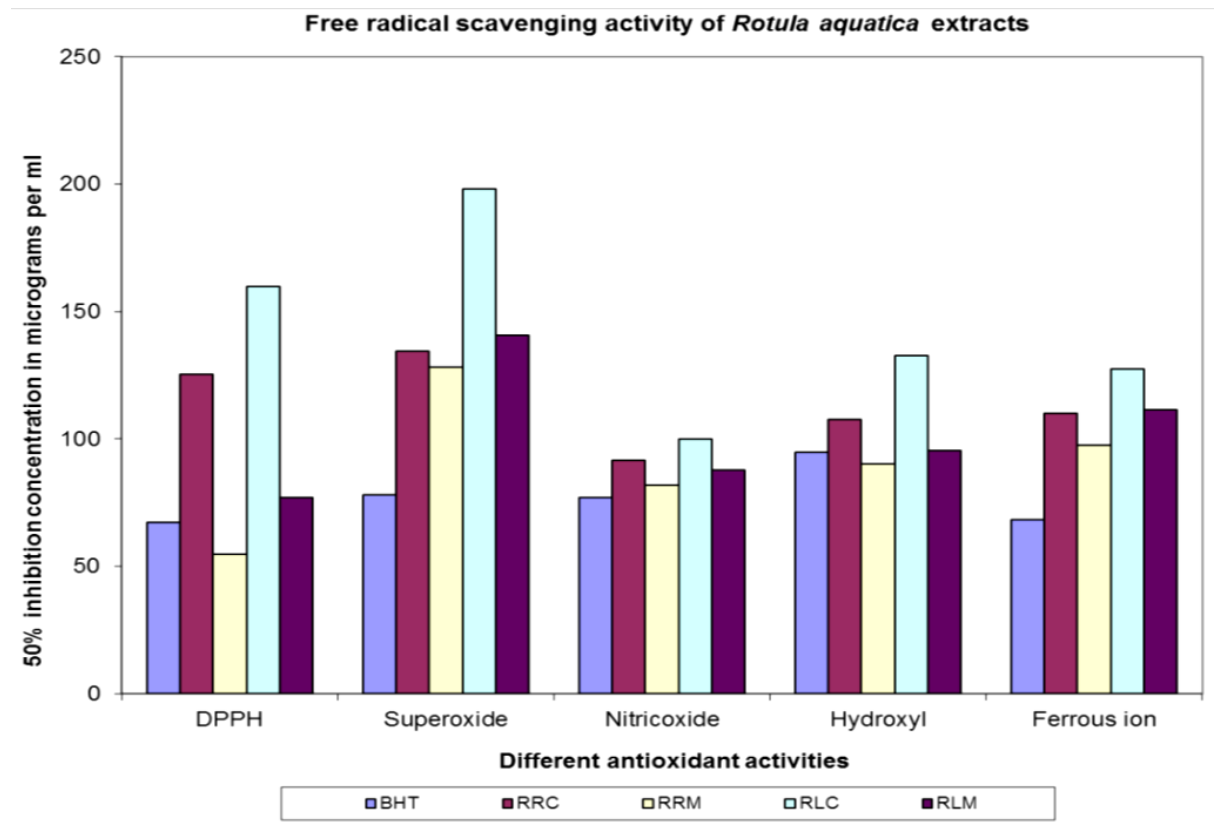

Fig. 3:Different radical scavenging activities of Rotula aquatica extracts at different concentrations (BHT-Standard, RRC- Rotula aquatica root Chloroform extracts and RRM-Rotula aquatica root methanol extract, RLC- Rotula aquatica leaf chloroform extract and RLM-Rotula aquatica leaf methanol extract)

\section{DPPH radical scavenging activity}

DPPH radical scavenging activity of the different extracts at varying concentrations were measured along with standard BHT. The methanolic extract of roots and leaves exhibited significant DPPH radical scavenging activity, with 50\% inhibition $\left(\mathrm{IC}_{50}\right)$ at a concentration of $54.68 \mu \mathrm{g} / \mathrm{ml}$ and $77.01 \mu \mathrm{g} / \mathrm{ml}$ respectively. While the chloroform extracts of roots and leaves showed $\mathrm{IC}_{50}$ value of $125.31 \mu \mathrm{g} / \mathrm{ml}$ and $159.74 \mu \mathrm{g} / \mathrm{ml}$ respectively. The $\mathrm{IC}_{50}$ value of methanolic extract of root was found to be less than that of BHT $(67.38 \mu \mathrm{g} / \mathrm{ml})$ (Fig 3). It is evident from the results that roots methanol extract had the strongest radical scavenging activity compared to the other extracts.

\section{Superoxide anion scavenging activity}

The superoxide anion radical scavenging activity of the extracts from Rotula aquatica assayed by the PMS/ NADH system is shown in Fig.3. The methanolic extracts of roots and leaves were found to possess good scavenging activity with $\mathrm{IC}_{50}$ values of $128.27 \mu \mathrm{g} / \mathrm{ml}$ and $134.51 \mu \mathrm{g} / \mathrm{ml}$ respectively, whereas chloroform extracts of roots and leaves showed $50 \%$ inhibition at a concentration of $140.64 \mu \mathrm{g} / \mathrm{ml}$ and $198.01 \mu \mathrm{g} / \mathrm{ml}$ respectively. BHT showed $50 \%$ inhibition at $78.07 \mu \mathrm{g} / \mathrm{ml}$.

\section{Nitric oxide radical scavenging activity}

The extracts of Rotula aquatica showed a better activity in competing with oxygen to react with nitric oxide and thus the inhibition of anions.

The chloroform and methanol extracts of Rotula aquatica roots exhibited an $\mathrm{IC}_{50}$ values of $91.65 \mu \mathrm{g} / \mathrm{ml}$ and $81.98 \mu \mathrm{g} / \mathrm{ml}$, however the corresponding leaves extract showed $50 \%$ inhibition at a concentration of $99.90 \mu \mathrm{g} / \mathrm{ml}$ and $87.65 \mu \mathrm{g} / \mathrm{ml}$ respectively whereas BHT has lower $\mathrm{IC}_{50}$ value of $77.05 \mu \mathrm{g} / \mathrm{ml} \mathrm{Fig} 3$. 


\section{Hydroxyl radical scavenging activity}

All the extracts shown the scavenging ability at varying concentration ranges against the hydroxyl radicals generated in a Fenton reaction system. Among the extracts, hydroxyl radical scavenging was found to be high in roots methanol extract followed by roots chloroform, leaves methanol and chloroform extracts with $\mathrm{IC}_{50}$ values of $90.20 \mu \mathrm{g} / \mathrm{ml}, 107.64 \mu \mathrm{g} / \mathrm{ml}, 95.49 \mu \mathrm{g} / \mathrm{ml}$ and $132.62 \mu \mathrm{g} / \mathrm{ml}$ respectively. The scavenging activity of different extracts measured against hydroxyl radical is as shown in Fig 3. The $\mathrm{IC}_{50}$ value of methanolic extract of root was found to be less than that of BHT $(90.20 \mu \mathrm{g} / \mathrm{ml})$.

\section{Ferrous ion chelating activity}

The methanol and chloroform extracts of roots possessed potent iron chelating activity with $\mathrm{IC}_{50}$ values of $97.33 \mu \mathrm{g} / \mathrm{ml}$ and $110.13 \mu \mathrm{g} / \mathrm{ml}$ compared to methanol and chloroform extracts of leaves with $50 \%$ inhibition concentrations of $111.28 \mu \mathrm{g} / \mathrm{ml}$ and $127.38 \mu \mathrm{g} / \mathrm{ml}$ respectively, while the reference antioxidant BHT, showed relatively higher ion chelating activity with $\mathrm{IC}_{50}$ at $68.32 \mu \mathrm{g} / \mathrm{ml}$ (Fig 3).

In recent years, potent free radical scavengers have attracted a tremendous interest as possible therapeutics against free radical mediated diseases. Free radicals are constantly generated in cells, either as accidental by-products of metabolism or deliberately (Jamuna et al., 2010). When an imbalance between free radical generation and body defense mechanisms occurs, oxidative damage will spread over all the cell targets (DNA, lipids, and proteins). It has been reported that a series of human illness such as cancer, atherosclerosis, cardio and cerebrovascular diseases, diabetes, immune system impairment, neurodegenerative diseases can be linked to the damaging action of extremely reactive free radicals (Mruthunjaya et al., 2008). There is increasing evidence that indigenous antioxidants may be useful in preventing the deleterious consequences of oxidative stress and there is increasing interest in the protective biochemical functions of natural antioxidants contained in spices, herbs and medicinal plants (Osawa, 1994 and Noda et al., 1997).

In the present study, Rotula aquatica roots and leaves extracts were tested for different phytoconstituents along with its total phenolics and antioxidant potentials. The result of qualitative phytochemical analysis revealed that, Rotula aquatica chloroform and methanolic extracts are bestowed with the presence of several bioactive compounds viz. glycosides, alkaloids, flavonoids, tannins and polyphenols which therefore encourages further antioxidant studies.

From the observations it was reported that the root methanol extract possessed high level of polyphenolic compounds. Further, free radical scavenging activity of methanolic and chloroform extracts of Rotula aquatica roots and leaves were assessed using various in vitro radical scavenging activities such as DPPH, superoxide anion, nitric oxide, hydroxyl and iron chelating activity at different concentrations. From the results it was observed that the methanolic root extract showed highest antioxidant potential followed by methanolic leaf, chloroform root and chloroform leaf extracts in terms of in vitro antioxidant parameters experimented. It is significant to note that the root extract showed a higher potency than the standard in scavenging of DPPH free radical.

It is obvious from the study, that the investigated extracts have the ability to quench free radicals. This may be due to chemical structure that can provide the necessary component as a radical scavenger and they contribute directly to antioxidative action in this plant extract. (Hatano et al., 1989; Duh et al., 1999 and Bhanu Priya et al., 2013). This feature perhaps may be due to the presence of active constituents viz. polyphenols, tannins, flavonoids, glycosides etc., identified in the plant, which have been documented for their antioxidant activity and therefore may be of immense value for further studies to unravel novel compounds and subsequent treatment strategies for disorders associated with free radicals induced tissue damage (Geissman, 1963; Saravana Kumar et al., 2008; Jamuna et al., 2011 and Vijayakumari et al., 2013).

\section{CONCLUSION}

The present study suggest that the Rotula aquatica extracts possess potent antioxidant activity, which might be helpful in preventing or slowing the progress of various oxidative stress- related diseases. Further investigation on the isolation and identification of antioxidant component(s) in the plant may be therefore highly rewarding.

\section{REFERENCES}

Beris, H. Antioxidant effects a basis of drug selection. Drugs, $1991 ; 42: 569-605$

Bhanu Priya, Sarika Zade R, Anish Shaikh, Manoj Gahlot, Punam Joshi. in vitro antioxidant activity and determination of total phenolic, flavonoid contents of stems of Rotula aquatica Lour. Int J Pharm Sci Res, 2013; 4(9):3608-3614.

Chandler SF, Dodds JH. The effect of phosphate, nitrogen and sucrose on the production of phenolics and solasidine in callus cultures of Solanum laciniatum. Plant Cell Rep, 1993; 2:1005-1010.

Cuendet M, Hostettmann K, Potterat O. Iridoidglucosides with free radical scavenging properties from Fagraeablumei. Hel Chim. Act, 1997; 80:1144-52.

Devasagayam TPA, Tilak JC, Boloor KK, Ketaki Sane S,Saroj Ghaskadbi S, Lele RD. Free Radicals and Antioxidants in Human Health: Current Status and Future Prospects. J Ass Phy Ind, 2004; 52: 794 804.

Dinis TCP, Madeira VMC, Almeidam LM. Action of phenolic derivates as inhibitors of membrane lipid peroxidation and peroxylradicals scavengers. Ach Biochem Biophy, 1994; 315:161-169.

Duh PD, Tu YY, Yen GC. Antioxidant acitvity of aqueous extract of harnjyur (Chrysanthemum morifolium Ramat). Leb mitt Wis cha Tech. 1999; 32: 269-77.

Garrat DC. The quantitative analysis of drugs Japan: Chapman and Hall. Pharm mag, 1964; 3: 456-458.

Gayatri Nahak, Sahu RK. in vitro antioxidative acitivity of Azadirachta indica and Melia azedarach Leaves by DPPH scavenging assay. J Am Sci, 2010; 6(6):123.

Geissman TA, Flavanoid compounds, tannins, lignins and related compounds. Elsevier, 1963; 9:265. 
Hatano T, Edamatsu R, Hiramatsu M, Mori A, Fujita Y, Yasuhara A. Effects of interaction of tannins with co-existing substances. VI. Effects of tannins and related polyphenols on superoxide anion radical and on DPPH radical. Chem Pharm Bull, 1989; 37: 2016-21.

Jamuna KS, Ramesh CK, Srinivasa TR, Raghu KL. Comparative studies on DPPH and reducing power antioxidant properties in aqueous extracts of some common fruits. J Pharm Res, 2010; 3(10): 2378-2380.

Jamuna KS, Ramesh CK, Srinivasa TR, Raghu KL. in vitro antioxidant studies in some common fruits, Int J Pharm Pharm Sci, 2011; 3(1): 60-63.

Kokate CK, Purohith AP, Gokhale SB. 1990. Pharmacognosy. Nirali Prakashan, Pune,; 120.

Liu F, Ooi VEC, Chang ST. Free radical scavenging activity of mushroom polysaccharide extracts. Lif Sci, 1997; 60: 763-771.

Mc Clements J, Decker EA. Lipid oxidation in oil-water emulsions: impact of molecular environment or chemical reactions in heterogeneous food system. J Food Sci, 2000; 65:1270-1282.

Mruthunjaya $\mathrm{K}$ and Hukkeri VI. in vitro Antioxidant and free radical scavenging potential of Parkinsonia aculeate Linn. Phcog Mag, 2008; 4(13), 42-51.

Noda Y, Anzai-Kmori A, Kohono M, Shimnei M, Packer L. Hydroxyl and superoxide anion radical scavenging activities of natural source antioxidants using the computerized JES-FR30 ESR spectrometer system. Biochem Mol Biol, 1997; 42: 35-44.

Osawa T. 1994. Novel neutral antioxidant for utilization in food and biological systems, Japan Scientific Societies Press, 241-251.

Patil S, Jolly CI, Narayanan S. Evaluation of Antimitotic activity of the root of Rotula aquatica (Lour): A traditional herb used in the treatment of cancer. Ind J exp bio, 2004; 42:893-899.
Rastogi RP, Mehrotra BN. 1959. Compendium of Indian Medicinal Plant.Vol.1: New Delhi, National institute of science Communication.

Saravana Kumar, Avijit Mazumder, Vanitha J, Venkateshwaran K, Kamalakannana K and Sivakumara T. Evaluation of Antioxidant Activity, Phenol and Flavonoid Contents of Some Selected Indian Medicinal Plants. Phcog Mag, 2008; 4.

Sies H. 1986. Biochemistry of Oxidative Stress. Angew Chem Internat Ed Eng, 25:1058-71

Suvakanta Dash, Lila KantaNath, Satish Bhise, Nihar Bhuyan. Antioxidant and antimicrobial activities of Heracleum nepalense, Tro $\mathrm{J}$ Pharm Res, 2005; 4(1): 341-347

Trease GE, Evans WC. 1978. A Text book of Pharmacognosy. $11^{\text {th }}$ edition, Bailliere Tidall, London: 530.

Velavan S, Nagulendran K, Mahesh R, Hazeena Begum V. in vitro antioxidant activity of Asparagus racemosus root. Pharm mag, 2007; 3:0973-1296.

Vijayakumari B, Sumithra S, Sasikala V, Radha S R. Evaluation of enzymatic and non-enzymatic antioxidant potential of Rotula aquatica Lour, J Pharm Res, 2013; 6(5):442.

$\mathrm{Yu}$ W, Zhao Y, Shu B. The radical scavenging activities of Radix puerariae iso flavonoids: A chemiluminescence study. Food Chem, 2004; 86:525-529.

\section{How to cite this article:}

Pallavi M, Ramesh C K, Krishna V, Channakeshava G H, Jamuna K S. Total Phenolics and Antioxidant Potentials of Rotula aquatica Lour. J App Pharm Sci, 2016; 6 (04): 169-174. 